THE WATER SUPPLY OF KENT.

THE question of water supply, a matter of such vital importance to corporate life, has been studied from the practical and theoretical standpoint by numerous authorities, but no hard-and-fast rules can be laid down, owing to the fact that general principles are subservient to local conditions. This is, perhaps, the reason why the leading authorities are so often contradictory.

Owing, partly, to the large area of its outcrop and subterranean extension beneath the Tertiary beds of the northern part of the county, partly to its great thickness, and partly to its unlimited capacity for water storage, the Chalk is the most important member of the Cretaceous series which is so finely developed in Kent, and yet it is rare to find two authorities agreeing on any point with regard to the behaviour of water in Chalk, while all speak from many years of experience.

The reason is that the question is far more complex than appears at first sight; as Whitaker points out, the absorbent capacity is modified by the extent of exposure, which is not always made clear by geological maps. The surface may be bare, in which case the absorptive power is very high, in some cases, where the Chall is open and fissured, large volumes of water being swallowed up with extraordinary rapidity; in others, where the soil is unusually thick or clayey, the absorption may be hindered; the case is modified by a covering of permeable beds such as Drift gravels and sand, and, again, where the Chalk is covered by beds of varying character, and, finally, where the Chalk is covered by beds of an impermeable character. Such an area as the latter is, of course, to be definitely excluded in calculating the absorptive area of the Chalk. In Kent this tract is confined to those districts where the London Clay covers the Chalk.

Again, the storing and transmitting capacity of the Chalk depends upon the physical nature of the different beds, and as in Kent the Chalk attains in many places a thickness of nearly 800 feet, it is obviously natural to find the different zones differing in character to a considerable extent; and yet engineering geologists have persistently ignored the value of a knowledge of the palæontological zones of the Chalk, of which eight are represented in Kent. There is no excuse for this apathy, since the work of Dr. Rowe has placed the geology of the Chalk upon a scientific footing. It is a striking fact that in all the literature quoted in the extensive bibliography, the author has only been able to find a single work dealing with the zones of Chalk from the point of view of the engineer.

In this memoir, one of the most useful that the Geological Survey has published, Mr. Whitaker discusses briefly the geological formations of Kent, and the nature and causes of the different kinds of springs occurring in the different beds, while a special chapter is devoted to swallow-holes and nailbournes, phenomena essentially characteristic of a Chalk area. A valuable chapter on the rainfall of Kent, illustrated by a map, is contributed by Dr. H. R. Mill.

The amount of water taken from springs in Kent is very small; there are only two large supplies, those for Maidstone and Folkestone, and neither of these is dependent upon the springs.

The Chalk area of Kent is pierced by very numerous wells for private or restricted use, but they are being rapidly superseded by the institution of

1 " The Water Supply of Kent ; with Records of Sinkings and Borings." By William Whitaker, F.R.S. With Contributions by Dr. H. Franklin Parsons, Dr. H. R. Mill, and Dr. J. C. Thresh. (Memoirs of the Geolngical for H.M. Stationery Office by Wyman and Sons, Ltd., rgo8.) Price 8 s. $6 d$. NO. 2067 , VOL. 80] larger corporate water works, which are only wells on a large scale. The quantity of water taken from surface deposits, as at Tunbridge Wells, from the Eocene beds, Lower Greensands, and sandy members of the Hastings beds, is insignificant compared with the amount provided by the Chalk, which supplies all the larger towns, as Ashford, Tonbridge, Dover, and the Kentish part of London.

Not the least interesting part of the book is the I47 pages occupied by sections of wells, and details of a large number of borings are also included.

Prominence is given to sections of some of the shafts and borings put down with the view of proving and working coal; these pages summarise our knowledge of the subterranean geology of Kent as it stood two years ago, but the impetus recently given by the new exploring companies since the discovery of the splendid coal-seams at the borings of Waldershare and Fredville has doubled the information available, though it has not yet all been made public. It is unfortunate that the author contented himself with the meagre sections of these two famous boreholes given by Boyd Dawkins in his evidence before the Royal Commission on Coal Supplies; if he had applied direct to the companies, the information would surely, have been willingly given.

The work is completed by a large number of analyses of both well and spring waters, and a number of notes on various subjects, some of considerable interest, such as the effect of heavy pumping, infiltration of salt water, and the deep borings at Cliffe and Frindsbury, but the vital question of pollution might have received more attention.

As a striking instance of the value of well-managed public water companies over purely local sources we may quote the following remarks from the report of an analysis of a sample of water from Delf stream, which gave drinking water to Sandwich until recently :-

" Colour objectionable, a dirty pale yellow; microscopic examination eminently unsatisfactory. The residue . . . . was full of animal matter; . . . it would be much more appropriate to call the liquid from this pump sewage rather than water.... however valuable this fluid might be as a liquid manure, and it would be impossible to deny that it has a certain value in this respect, it should not be used as water."

M. B.

\section{THE WINNIPEG MEETING OF THE BRITISH} ASSOCIATION.

THE British Association will hold its annual 1 meeting in Winnipeg from August 25 to September I, under the presidency of Sir J. J. Thomson, F.R.S.

Regular attendants at meetings of the Association have become accustomed to reminiscences of previous meetings in the same city. Thus, when the association meets in Great Britain, the expression "When we met here twenty-five years ago," or "At our meeting fifty years ago," has become a stereotyped part of the presidential addresses. A meeting of the association in Winnipeg thirty years, or even twentyfive years, ago would have been almost an impossibility. At that period Winnipeg was little more than a Hudson's Bay Company's trading post-Upper Fort Garry-the population of the scattered settlement numbering only some 2000 people, mostly farmers. Winnipeg could not have been reached by the Canadian Pacific main line until some six years later; passengers arrived by stern-wheel steamers of the Mississippi type from Moorhead, Minnesota, via the Red River; or came by irregular trains over the Great Northern Railway from St. Paul to St. Boniface 